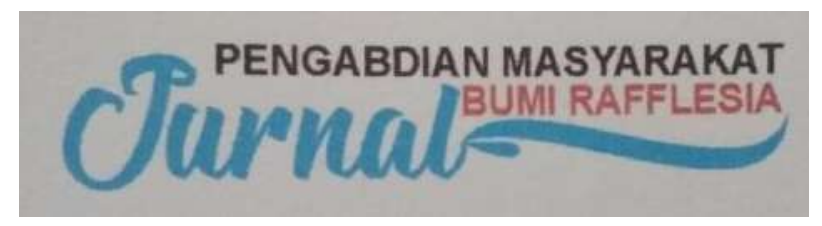

\title{
PELATIHAN DAN PENDAMPINGAN AKUNTANSI BERBASIS KOMPUTER PADA UMKM KABUPATEN PRINGSEWU, LAMPUNG
}

\author{
Arum Arupi Kusnindar, S.E, MBA \\ STIE Muhammadiyah Pringsewu Lampung \\ arumarupi@stiemuh-pringsewu.ac.id
}

\begin{abstract}
ABSTRAK
Akuntansi merupakan bagian dari pengeloaan keuangan perusahaan yang sangat penting. Apapun ukuran perusahaan membutuhkan akuntansi dalam mengelola keuangan dan menjadi alat bagi perusahaan untuk mengendalikan aktivitas perusahaan agar berjalan dengan baik dan mendapatkan laba sepertiyang di harapkan. Usaha Mikro kecil dan Menengah (UMKM) merupakan Usaha mikro dalam struktur perekonomian Indonesia mempunyai peran yang sangat strategis. Dengan melambatnya pertumbuhan ekonomi global, UMKM menjadi penyelamat bagi tetap tumbuhnya perekonomian Indonesia. Data Kemenkop UMKM RI menunjukan pada 2017 awal terdapat 58 juta kegiatan usaha secara mandiri (self employed) dan 99,9\% unit bisnis di Indonesia merupakan UKM yang mampu menyerap 97\% tenaga kerja Indonesia. Di Kabupaten Pringsewu terdapat 3.997 UMKM yang tersebar pada 9 Kecamatan. Jumlah UMKM di kecamatan pringsewu paling banyak disbanding kecamatan lain karena Pringsewu merupakan ibukota Kabupaten. Banyaknya pengusaha UMKM di Pringsewu tidak di imbangi kemampuan pengusaha dalam mengelola keuangan melalui Akuntansi. Keenganan mereka menerapkan akunatnsi dengan benar disertai dengan beberapa alasan seperti tidak pahak akuntansi, tidak mempunyai computer, tidak ada waktu serta merasa bahwa akuntansi tidak bermanfaat. Oleh karena itu, pelatihan ini bertujuan untuk memberikan pemahaman proses akuntansi untuk UMKM termasuk di dalamnya memberikan pelatihan menggunakan computer dalam mengolah data keuangan sampai dengan menjadi laporan keuangan.
\end{abstract}

Kata Kunci: Akuntansi, UMKM, Laporan Keuangan, Komputer

\section{PENDAHULUAN}

Setelah krisis ekonomi tahun 1998, Usaha Mikro, Kecil dan Menengah menjadi sangat strategis karena mereka terbukti kokoh dalam menghadapi krisis. Data dari Biro Pusat Statistik menunjukan bahwa jumlah UKM setelah krisis tahun 1998, tidak berkurang namun justru meningkat dan mampu menyerap 85 sampai dengan 100 juta tenaga kerja. Komitmen pemerintah di tunjukan dengan terbitnya UU no 20 tahun 2008 mengenai UKM yang kemudian diikuti dengan kebijakan dan paket ekonomi yang mendorong pertumbuham UKM. Definisi UKM menurut UU No. 20 tahun 2008 adalah "sebuah perusahaan di golongkan sebagai UKM 
jika dimiliki dan di kelola oleh seseorang atau sekelompok kecil orang dengan jumlah kekayaan dan pendapatan tertentu."

UU No 20 tahun 2008 juga mengklasifikasikan UKM kedalam beberapa kategori yaitu berdasarkan karakteristik yang membedakan UKM dengan usaha besar dan Berdasarkan Asset dan Modal. Di bawah ini adalah tabel yang menunjukan klasifikasi UKM

\section{Tabel 1.1 Kriteria UKM dan Usaha Besar Berdasarkan Asset dan Omset}

\begin{tabular}{|l|l|l|}
\hline \multirow{2}{*}{$\begin{array}{l}\text { Ukuran } \\
\text { Usaha }\end{array}$} & \multicolumn{2}{|l|}{ Kriteria } \\
\cline { 2 - 3 } & Aset & Omset \\
\hline Usaha & Maksimal & Maksimal \\
Mikro & Rp. 50 Juta & Rp.300 juta \\
\hline Usaha & $>$ Rp.50 & $>$ Rp.300 juta - \\
Kecil & juta - & Rp.2,5 Milliar \\
& Rp.500 juta & \\
\hline $\begin{array}{l}\text { Usaha } \\
\text { Menengah }\end{array}$ & juta Rp.500 & $>$ Rp.2,5 milliar \\
& Rp.10 & - Rp.50 Milliar \\
& miliar & \\
\hline $\begin{array}{l}\text { Usaha } \\
\text { besar }\end{array}$ & $>$ Rp.10 & $>$ Rp.50 milliar \\
\hline
\end{tabular}

Sumber : Kementrian Koperasi dan UKM, 2014

Dalam rangka pemberdayaan UMKM di Indonesia, Bank Indonesia (2011) mengembangkan filosofi lima jari/ Five finger philosophy, maksudnya setiap jarimempunyai peran masing-masing dan tidak dapat berdiri sendiri serta akan lebih kuatjika digunakan secara bersamaan.

1. Jari jempol, mewakili peran lembaga keuangan yang berperan dalam intermediasikeuangan, terutama untuk memberikan pinjaman/pembiayaan kepada nasabahmikro, kecil dan menengah serta sebagai Agents of development (agen pembangunan).

2. Jari telunjuk, mewakili regulator yakni Pemerintah dan Bank Indonesia yang berperandalam Regulator sektor riil dan fisKAL Menerbitkan ijin-ijin usahaUMKM serta menciptakan iklimyang kondusif dan sebagai sumber pembiayaan.

3. Jari tengah, mewakili katalisator yang berperan dalam mendukung perbankan dan UMKM

4. Jari manis, mewakili fasilitator yang berperan dalam mendampingi UMKM,khususnya usaha mikro, membantu UMKM untuk memperoleh pembiayaan bank, dan konsultasi pengembangan UMKM.

5. Jari kelingking, mewakili UMKM yang berperan dalam pelaku usaha

Perguruan tinggi, mereprensentasikan Jari Manis yang menjadi pendamping dan mendukung usaha UMKM agar lebih berkembang. Proses pendampingan yang dilakukan perguruan tinggi bisa dilakukan melalui berbagai bentuk yaitu penelitian, yaitu dengan menghasilkan tekhnologi tepat guna atau melalui pengabdian kepada masyarakat melalui $\mathrm{KKN}$ atau program program kewirausahaan.

Pada tahun 2015, jumlah UKM di Kabupaten Pringsewu berjumlah 1.676 yang terbagi ke dalam 14 kategori tipe industri dan tersebar ke dalam 9 kecamatan serta mampu menyerap 19.423 tenaga kerja dari 33.420 tenaga kerja atau sebesar $60 \%$. Untuk tahun 2017, jumlah UKM meningkat menjadi 3.888 unit dan mampu menyerap $70 \%$ tenaga kerja. Pringsewu sebagai kecamatan yang terpadat pendudukannya juga merupakan kecamatan yang mempunyai jumlah unit usaha paling banyak.

Dalam postur APBD Kabupaten Pringsewu, Pertanian, Kehutanan dan Perikanan memberikan kontribusi terbesar sebesar 1.7 milyar pertahun diikuti oleh perdagangan besar dan eceran, reparasi mobil dan industri pengolahan. Dalam table di bawah ini di tunjukan jumlah unit usaha yang ada di Kabupaten Pringsewu Pada Maret 2017. 
TABEL 1.2 JUMLAH UNIT USAHA, OMSET
DI KABUPATEN PRINGSEWU MARET 2018

\begin{tabular}{|c|c|c|c|c|c|c|}
\hline \multirow[b]{2}{*}{ zz } & \multirow{2}{*}{$\begin{array}{l}\bar{\pi} \\
\bar{\lambda} \\
2 \\
2 \\
2 \\
2 \\
2 \\
2\end{array}$} & \multicolumn{3}{|c|}{$\begin{array}{c}\text { JUMLAH UNIT } \\
\text { USAHA }\end{array}$} & \multirow[b]{2}{*}{$\begin{array}{c}\text { OMS } \\
\text { ET/T } \\
\text { HN }\end{array}$} & \multirow{2}{*}{$\begin{array}{c}\text { ASSET } \\
\text { (dalam } \\
\text { juta } \\
\text { rupiah) }\end{array}$} \\
\hline & & 光 & 齐 & 泶 & & \\
\hline 1 & 2 & 3 & 4 & 5 & 9 & 10 \\
\hline 1 , & $\begin{array}{l}\text { PRIN } \\
\text { GSE } \\
\text { WU }\end{array}$ & 1059 & 244 & 29 & $111.039,97$ & $61.688,87$ \\
\hline 2 , & $\begin{array}{l}\text { GADI } \\
\text { NGR } \\
\text { EJO }\end{array}$ & 643 & 202 & 9 & $60.049,62$ & $33.360,90$ \\
\hline 3 , & $\begin{array}{l}\text { BAN } \\
\text { YUM } \\
\text { AS }\end{array}$ & 304 & 114 & 0 & $30.268,80$ & $16.816,00$ \\
\hline 4 , & $\begin{array}{l}\text { PAGE } \\
\text { LAR } \\
\text { AN }\end{array}$ & 387 & 31 & 1 & $19.330,92$ & $10.739,40$ \\
\hline 5 , & $\begin{array}{l}\text { SUK } \\
\text { OHA } \\
\text { RJO } \\
\end{array}$ & 178 & 57 & 2 & $17.069,22$ & $9.482,90$ \\
\hline 6 , & $\begin{array}{l}\text { AMB } \\
\text { ARA } \\
\text { WA }\end{array}$ & 165 & 66 & 0 & $16.428,60$ & $9.127,00$ \\
\hline 7 , & $\begin{array}{l}\text { PAR } \\
\text { DAS } \\
\text { UKA }\end{array}$ & 101 & 35 & 0 & $11.666,70$ & $6.481,50$ \\
\hline 8, & $\begin{array}{l}\text { ADIL } \\
\text { UWI } \\
\mathrm{H}\end{array}$ & 216 & 19 & 1 & $11.373,75$ & $6.318,75$ \\
\hline 9, & $\begin{array}{l}\text { PAGE } \\
\text { LAR } \\
\text { AN } \\
\text { UTA } \\
\text { RA }\end{array}$ & 23 & 2 & 0 & $1.116,90$ & 620,50 \\
\hline & $\begin{array}{l}\text { Juml } \\
\text { ah }\end{array}$ & 3076 & 770 & 42 & $278.344,48$ & $\begin{array}{c}154.635,8 \\
2\end{array}$ \\
\hline
\end{tabular}

Khusus untuk Kecamatan Pringsewu mempunyai 1.332 unit usaha yang terdiri dari 1.059 usaha mikro, 244 usaha kecil dan 29 usaha menengah. Tiga kelompok usaha terbesar di Pringsewu jika di bagi kedalan industri Agro dan Non Agro. Pada kelompok Agro, jenis industri terbesar adalah gilingan padi, tahu dan tempe dan makanan ringan. Sedangkan, pada Non
Agro, jenis industri terbesar adalah genteng, bata merah, dan kain perca. Data dapat diliha pada Uab KMY Mibawah ini:

\section{Tabel 1.3 Tabel Jumlah unit usaha agro dan non Agro}

\begin{tabular}{|c|c|c|c|}
\hline \multicolumn{2}{|c|}{ Industri Agro } & \multicolumn{2}{c|}{ Industri Non Agro } \\
\hline Jenis Industri & Unit Usaha & $\begin{array}{c}\text { Jenis } \\
\text { Industri }\end{array}$ & $\begin{array}{c}\text { Unit } \\
\text { Usaha }\end{array}$ \\
\hline Gilingan Padi & 158.00 & Genteng & 493.00 \\
\hline Tahu,Tempe & 188.00 & $\begin{array}{c}\text { bata } \\
\text { Merah }\end{array}$ & 980.00 \\
\hline makanan ringan & 254.00 & $\begin{array}{c}\text { Kain } \\
\text { Perca }\end{array}$ & 101.00 \\
\hline TOTAL & $\mathbf{6 0 0 . 0 0}$ & & $\mathbf{1 , 5 7 4 . 0 0}$ \\
\hline
\end{tabular}

Berikut adalah peta wilayah kecamatan Pringsewu, beserta beberapa foto yang menunjukan potensi UMKM di Kecamatan Pringsewu.

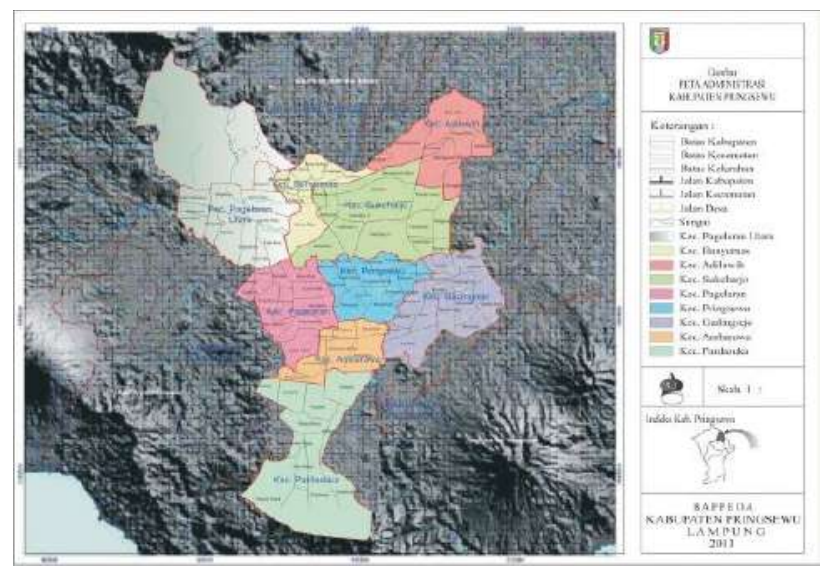

Beberapa UMKM yang ada di Pringsewu sebagai berikut:

\section{Foto 1: UKM Toku Buah Pohon Asem}




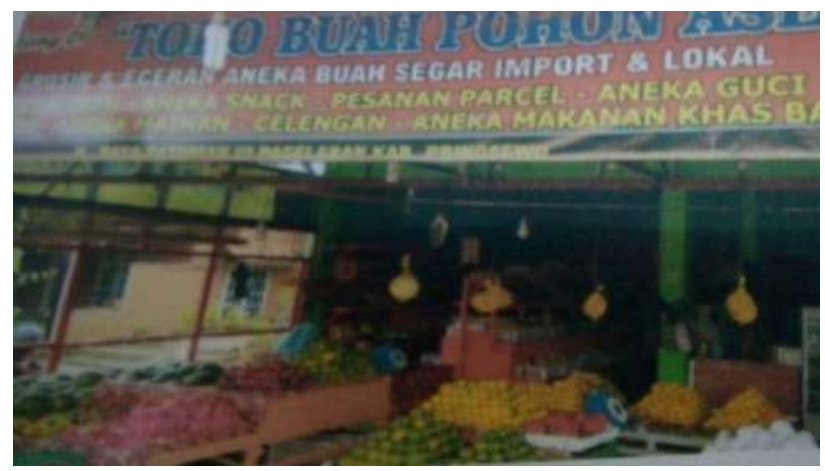

Foto 2: Toko Tong Hilap Nya

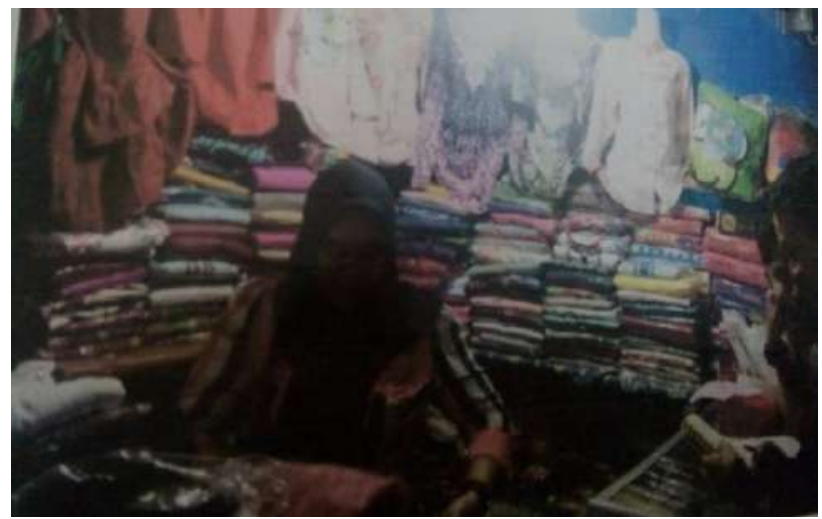

Pesatnya pertumbuhan UMKM di Pringsewu, tidak sebanding dengan sumbangan UMKM pada PDRB Kabupaten Pringsewu. Sampai dengan Maret 2017 keseluruhan produksi UKM di 9 kecamatan mencapai 304.8 Milyar atau hanya 3\% dari total PDRB Kabupaten Pringsewu yang mencapai 8.8 Trilyun. Padahal jumlah UKM tumbuh pesat dari 1.676 di tahun 2015 menjadi 3.888 pada 2017. Kontribusi UKM yang kecil menjadi salah satu kondisi yang mengakibatkanlaju pertumbuhan ekonomi daerah Pringsewu dari tahun 2014 - 2016 mengalami perlambatan. Dari $5,22 \%$ di tahun 2015 menjadi $5.04 \%$ di tahun 2016.

Kecilnya pendapatan UMKM menunjukan kemampuan para pengusaha UMKM dalam mengembangkan usahanya masih sangat terbatas.Elisabeth dkk (2012) mengemukakan dalam penelitiannya bahwa Sebagian besar UMKM hanya melakukan pencatatan uang masuk, uang keluar, pembelian dan penjualan. Mereka belum mampu mengkombinasikan laporan tersebut dalam sebuah bentuk laporan keuangan. Hambatan terbesar bagi UMKM adalah keterbatasan pengetahuan mereka terhadap akuntansi.Dalam penelitian lain Kusnindar (2017) menemukan bahwa hambatan terbesar bagi UMKM untuk memakai tekhnologi komputer dan internet dalam pengelolaan usaha mereka adalah faktor sumber daya manusia. Dalam penelitain lain, Malia (2017) juga mengemukaan bahwa pengetahuan mengenai akuntansi sangat berpengaruh terhadap kemampuan menyusun laporan keuangan pada para pengurus koperasi dan UMKM di kabupaten Pringsewu.

Penulis yang kerap kali menjadi narasumber pada berbagai pelatihan UMKM juga menemukan fakta bahwa pengusaha UMKM menyadari benar pentingnya akuntansi serta komputer dalam mengelola usaha mereka, namun keterbatasan pengetahuan dan umur membuat mereka enggan untuk belajar.Mereka mengharapkan ada pelatihan yang dilakukan secara personal dan dengan pendekatan praktik, sehingga mereka benar - benar mampu menguasai kemampuan dalam akuntansi dan komputer.

\section{TUJUAN DAN MANFAAT}

Tujuan dan manfaat dari kegiatan pelatihan dan Pendampingan ini adalah sebagai berikut:

a. Membantu UMKM memahami akuntansi dan mampu melakukan pengolahan transaksi keuangan dengan benar sampai dengan menghasilkan laporan keuangan

b. Membantu UMKM melakukan pengolahan transaksi dengan komputer, sehingga proses pembuatan laporan keuangan lebih cepat dan akurat

c. Membantu UMKM agar dapat memahami laporan keuangan yang dihasilkan sehingga mampu di gunakan untuk pengambilan keputusan

d. Memberikan pendampingan selama 3 bulan untuk memastikan mereka mampu memahami pelatihan yang di berikan dan mempergunakannya dalam pengelolaan usaha mereka. 


\section{METODE KEGIATAN}

\subsection{Waktu dan Tempat Kegiatan}

Kegiatan ini terbagi ke dalam dua periode. Kegiatan pertama adalah pelatihan dan kegiatan kedua adalah pendampingan. Peserta kegiatan pelatihan dan pendampingan ini terdiri dari 12 UMKM dari kabupaten pringsewu, yang mempunyai usaha beragam. Di bawah ini adalah daftar peserta kegiatan:

Table 3.1 Peserta kegiatan Pelatihan dan Pendampingan

\begin{tabular}{|l|l|l|l|}
\hline No & Nama Usaha & $\begin{array}{l}\text { Jenis } \\
\text { Usaha }\end{array}$ & Alamat \\
\hline 1 & $\begin{array}{l}\text { Tk. Buah Pohon } \\
\text { Asem }\end{array}$ & $\begin{array}{l}\text { Perdagang } \\
\text { an Eceran }\end{array}$ & Kec.Pagelaran \\
\hline 2 & $\begin{array}{l}\text { Rumah Produksi } \\
\text { Kado rama }\end{array}$ & Kerajinan & $\begin{array}{l}\text { Kec. } \\
\text { Peringsewu }\end{array}$ \\
\hline 3 & $\begin{array}{l}\text { Rumah Makan } \\
\text { Sendok Sumpit }\end{array}$ & Kuliner & $\begin{array}{l}\text { Kec. } \\
\text { Pringsewu }\end{array}$ \\
\hline 4 & $\begin{array}{l}\text { Toko Amparan } \\
\text { Buah Manis }\end{array}$ & $\begin{array}{l}\text { Perdagang } \\
\text { an Eceran }\end{array}$ & Kec.Pringsewu \\
\hline 5 & $\begin{array}{l}\text { BFC Kuntao } \\
\text { Dewo }\end{array}$ & Kuliner & $\begin{array}{l}\text { Kec. } \\
\text { Ambarawa }\end{array}$ \\
\hline 6 & Bakso King & Kuliner & $\begin{array}{l}\text { Kec. } \\
\text { Sukoharjo }\end{array}$ \\
\hline 7 & $\begin{array}{l}\text { Indo Helmet } \\
\text { Gallery }\end{array}$ & $\begin{array}{l}\text { Perdagang } \\
\text { an eceran }\end{array}$ & $\begin{array}{l}\text { Kec. } \\
\text { Pringsewu }\end{array}$ \\
\hline 8 & Bengkel Udin & $\begin{array}{l}\text { Jasa } \\
\text { Service }\end{array}$ & $\begin{array}{l}\text { Kec. } \\
\text { Pringsewu }\end{array}$ \\
\hline 9 & Isa COM & $\begin{array}{l}\text { Jasa } \\
\text { komputer }\end{array}$ & $\begin{array}{l}\text { Kec. } \\
\text { Pringsewu }\end{array}$ \\
\hline 10 & $\begin{array}{l}\text { Brilink Rantau } \\
\text { Tihjang }\end{array}$ & $\begin{array}{l}\text { Jasa } \\
\text { keuangan }\end{array}$ & $\begin{array}{l}\text { Kec.Talang } \\
\text { Padang }\end{array}$ \\
\hline 11 & Wawan Motor & $\begin{array}{l}\text { Jasa } \\
\text { Service }\end{array}$ & $\begin{array}{l}\text { Kec. } \\
\text { Pringsewu }\end{array}$ \\
\hline 12 & $\begin{array}{l}\text { Tk.TongHilapnya } \\
\text { Buah Manis }\end{array}$ & $\begin{array}{l}\text { Perdagang } \\
\text { an Eceran }\end{array}$ & \begin{tabular}{l} 
Kec.Pringsewu \\
\hline
\end{tabular} \\
\hline
\end{tabular}

\subsubsection{Kegiatan Pelatihan}

Kegiatan Pelatihan di lakukan pada 10 September 2018 bertempat di Lab. Komputer STIE Muhammadiyah Pringsewu, dari pukul 08.00 WIB sampai dengan 16.00 WIB. Kegiatan pelatihan di bantu oleh beberapa mahasiswa dari kelas komputer akuntansi. Setiap peserta langsung praktek pada komputer, sehingga selesai pelatihan mereka membawa ketrampilan baru.
Materi yang di sampaikan pada kegiatan pelatihan ini adalah:

a. Akuntansi Dasar

Akuntansi dasar meliputi, tujuan mempelajari akuntansi, kegunaan akuntansi bagi organisasi dan sebagai dasar pengambilan keputusan, Siklus akuntansi dasar, bentuk bentuk laporan yang di butuhkan. Dilakukan dari Pukul $08.00-10.00 \mathrm{WIB}$

b. Pengolahan Transaksi (Cash Flow, Jurnal, Buku besar, neraca saldo, Laporan Keuangan).

Pengolahan transaksi meliputi, praktek menginput transaksi ke dalam cash flow, lalu melakukan jurnal, mampu menghasilkan buku besar dan neraca saldo, serta mampu membuat Harga pokok produksi, Rugi lama dan Neraca.Dilakukan dari pukul 10.00 WIB -15.00 WIB

c. Memperkenalkan komputer akuntansi

Materi ini, tergabung dengan materi pengolahan transaksi karena pengolahan transaksi yang di berikan memakai bantuan komputer dengan program excel. Dilakukan bersamaan dengan ateri kedua yaitu pda pukul $10.00-15.00 \mathrm{WIB}$

d. Melatih kemampuan penggunaan komputer akuntansi dengan software akuntansi berbasis excel yang sudah di siapkan oleh pelaksana kegiatan. Dilakukan dari Pukul 15.00 - 16.30 WIB Pada materi ini, peserta di minta belajar melakukan pengolahan transaksi yang real dari usaha mereka. Sebelum pelatihan, para peserta sudah di informasikan untuk membawa transaksi selama satu bulan sehingga mereka bisa belajar memakai transaksi real yang mereka hadapi sehari-hari.

Dokumentasi dari kegiatan pelatihan adalah sebagai berikut:

Foto 3: Pelatihan di Lab Komputer 


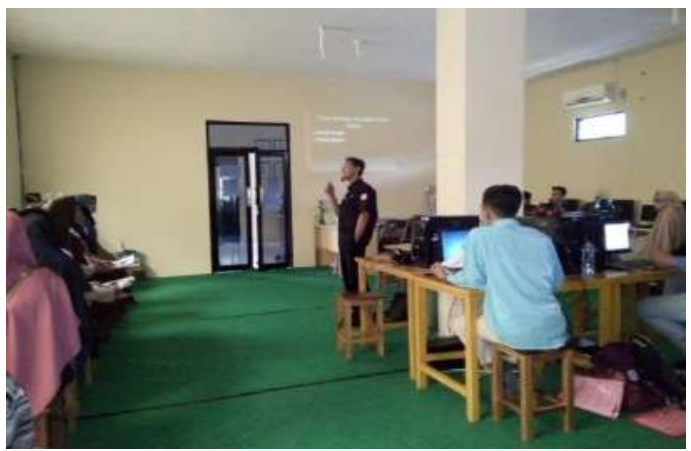

Materi Siklus Akuntansi

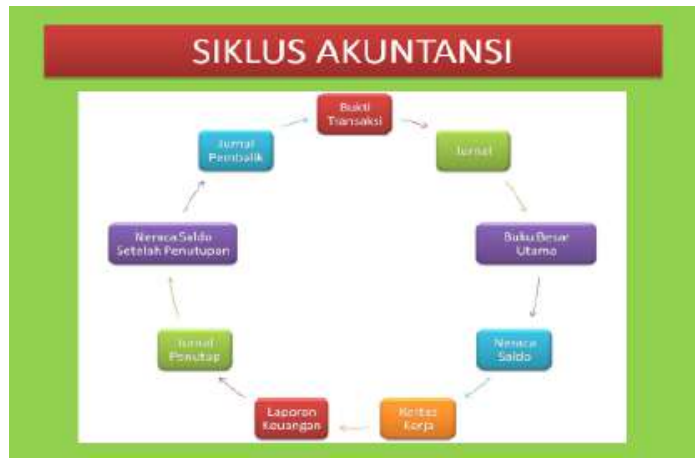

Materi Komputer Akuntansi

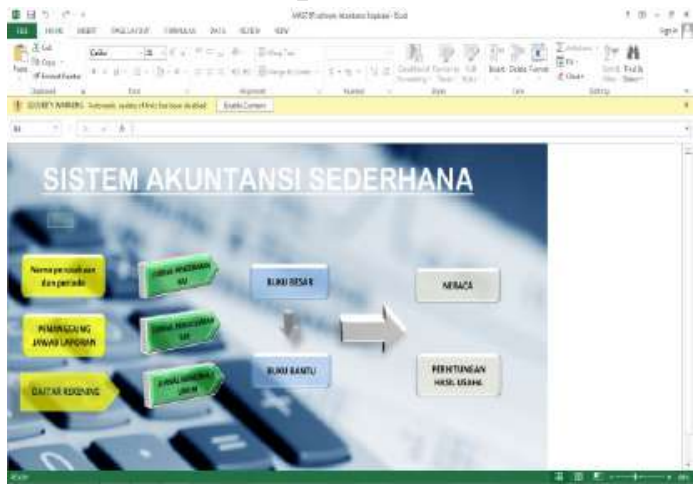

\subsubsection{Kegiatan Pendampingan}

Kegiatan Pendampingan dilakukan dalam beberapa tahapan, yaitu:

1. Membentuk kelompok pendamping

Terdapat 12 kelompok, sesuai dengan 12 UMKN yang telah mengikuti pelatihan sebelumnya. Anggota kelompok berasal dari Kelas Komputer Akuntansi. Setiap kelompok terdiri dari 6 sampai dengan 8 orang.

2. Pendamping kelompok adalah dosen mata kuliah Komputer Akuntansi yaitu penggagas dan penanggung jawab kegiatan pengabdian ini.

3. Kegiatan ini dilakukan dari bulan September 2018 sampai dengan January 2019.

4. Proses pendampingan sebagai berikut :

a. Setiap seminggu sekali kelompok datang ke Mitra UKM lalu melakukan penampingan dengan materi yang sudah di persiapkan.

b. Hasil dari pendampingan di konsultasikan kepada dosen pendamping. Jika diperlukan dosen pendamping akan melakukan kunjungan ke UKM untuk mencari solusi atas permasalahan yang ada.

c. Pada bulan terakhir, dilakukan pertemuan Antara anggota kelompok, dosen pendamping dan Mitra UKM. Untuk mendiskusikan hasil dari kegiatan pendampingan, masukan, kekurangan dan langkah selanjutnya yang bisa di lakukan demi kemajuan UKM.

d. Materi dalam pendampingan dapat dilihat pada table di bawah ini:

\begin{tabular}{|l|l|l|}
\multicolumn{3}{|c}{ Tabel 3.2 Materi Pendampingan } \\
\hline No & Materi & Waktu \\
\hline 1 & $\begin{array}{l}\text { Indentifikasi } \\
\text { permsalahan } \\
\text { administrasi keuangan }\end{array}$ & September \\
\hline 2 & $\begin{array}{l}\text { Pembuatan SIA ( Sistem } \\
\text { Informasi Akuntansi ) } \\
\text { flow chart dan semua } \\
\text { bentuk dasar dokumen } \\
\text { pendukung }\end{array}$ & Oktober \\
\hline 3 & $\begin{array}{l}\text { Pembuatan Sistem } \\
\text { akuntansi berbasis excel } \\
\text { di sesuaikan degan SIA } \\
\text { yang sudah di buat }\end{array}$ & November \\
\hline 4 & Trial $\rightarrow$ Eksekusi Sistem & Desember \\
\hline 5 & $\begin{array}{l}\text { Evaluasi Antara UKM, } \\
\text { pelaksana dan } \\
\text { penangung jawab } \\
\text { pendampingan }\end{array}$ & January \\
\hline
\end{tabular}

\section{HASIL DAN PEMBAHASAN}




\subsection{Kegiatan Pelatihan}

berikut:

Hasil dari kegiatan pelatihan sebagai

a. Peserta memahami fungsi dan manfaat mengelola admiistrasi keuangan dengan benar melalui akuntansi

b. Peserta, memahami proses yang dilakukan di dalam akuntansi dalam mengolah transaksi dari dokumen mentah sampai menjadi laporan keuangan

c. Peserta, mengenal computer akuntansi sebagai salah satu cara untuk mengolah transaksi keuangan menjadi laporan

d. Peserta mampu mengoperasikan sisten pengolahan transaksi berbasis excel dan mampu menyelesaikan latihan latihan yang di berikan pada sesi pelatihan

Secara umum, peserta sangat antusias dan menunggu jadwal pendampingan akan dilakukan. Mereka bahwa bersedia melakukan investasi dengan membeli computer atau laptop agar mereka mampu melakukan ssemua proses pengolahn transaksi sembari mereka melakukan penjualan.

Mereka memiliki pmehaman baru mengenai akuntansi, bahwa akuntansi tidak sulit dan membantu dalam pengambilan keputusan bisnis.

\subsection{Kegiatan Pendampingan}

Hasil dari kegiatan pendampingan beragam, karena kondisi setiap UKM berbeda. Beberapa UKM, sudahmempunyai pencatatan manual yang sangat rapi dan lengkap. Beberapa di antaranya bahkan tidak melakukan pencatatan. Sehingga hasil dan kegiatan pendampingan berbeda-beda. Dan dapat dilihat apd atabel di bawah ini:

\section{Tabel 4.1. Indentifikasi Awal UKM}

\begin{tabular}{|l|l|l|}
\hline No & Nama Usaha & Profil Awal \\
\hline 1 & Tk. Buah Pohon & $\begin{array}{l}\text { Sudah ada pencatatan } \\
\text { manual pada pembelian, } \\
\text { penjualan, uang masuk dan } \\
\text { Aang keluar, namun tidka }\end{array}$ \\
\hline
\end{tabular}

\begin{tabular}{|c|c|c|}
\hline & & $\begin{array}{l}\text { ada catatan persediaan dna } \\
\text { belummampu membuat } \\
\text { laporan keuangan }\end{array}$ \\
\hline 2 & $\begin{array}{l}\text { Rumah Produksi } \\
\text { Kado rama }\end{array}$ & $\begin{array}{l}\text { Belum ada pencatatan } \\
\text { apapun, hanya } \\
\text { mengumpulkan nota nota } \\
\text { pembelian, }\end{array}$ \\
\hline 3 & $\begin{array}{l}\text { Rumah Makan } \\
\text { Sendok Sumpit }\end{array}$ & $\begin{array}{l}\text { Sudah ada pencatatan } \\
\text { manual pada pembelian, } \\
\text { penjualan, uang masuk dan } \\
\text { uang keluar, namun tidka } \\
\text { ada catatan persediaan dna } \\
\text { belum mampu membuat } \\
\text { laporan keuangan dan } \\
\text { kesulitan dalam menentukan } \\
\text { harga pokok produksi }\end{array}$ \\
\hline 4 & $\begin{array}{l}\text { Toko Amparan } \\
\text { Buah Manis }\end{array}$ & $\begin{array}{l}\text { Pencatatan manual masih } \\
\text { sangat terbatas, yaitu hanya } \\
\text { pada bagian penjualan kredit } \\
\text { (pencatatan hutang) dan } \\
\text { pembelian kredit (pencatatan } \\
\text { piutang), tidak ada } \\
\text { pencatatan biaya }\end{array}$ \\
\hline 5 & $\begin{array}{l}\text { BFC Kuntao } \\
\text { Dewo }\end{array}$ & $\begin{array}{l}\text { Sudah ada pencatatan } \\
\text { manual pada pembelian, } \\
\text { penjualan, uang masuk dan } \\
\text { uang keluar, namun tidka } \\
\text { ada catatan persediaan dna } \\
\text { belum mampu membuat } \\
\text { laporan keuangan dan } \\
\text { kesulitan dalam menentukan } \\
\text { harga pokok produksi }\end{array}$ \\
\hline 6 & Bakso King & $\begin{array}{l}\text { Hanya da pencatatan uang } \\
\text { masuk dan uang keluar, } \\
\text { tidak pernah ada identifikasi } \\
\text { dan pencatatan biaya }\end{array}$ \\
\hline 7 & $\begin{array}{l}\text { Indo Helmet } \\
\text { Gallery }\end{array}$ & $\begin{array}{l}\text { Sudah ada pencatatan } \\
\text { manual pada pembelian, } \\
\text { penjualan, uang masuk dan } \\
\text { uang keluar, biaya, namun } \\
\text { belum mampu membuat } \\
\text { laporan keuangan }\end{array}$ \\
\hline 8 & Bengkel Udin & $\begin{array}{l}\text { Belum ada pencatatan } \\
\text { apapun, hanya } \\
\text { mengumpulkan nota nota } \\
\text { pembelian, bengkel } \\
\text { udinmerupakan UKM } \\
\text { dengan tantangan terbesar } \\
\text { karena jenis usaha tidak } \\
\text { hanya jasa tetapi juga jual } \\
\text { beli suku cadang kendaraan } \\
\text { yang jenisnya sangat banyak }\end{array}$ \\
\hline 9 & Isa COM & $\begin{array}{l}\text { Belum ada pencatatan } \\
\text { apapun, hanya } \\
\text { mengumpulkan nota nota } \\
\text { pembelian, }\end{array}$ \\
\hline 10 & $\begin{array}{l}\text { Brilink Rantau } \\
\text { Tihjang }\end{array}$ & $\begin{array}{l}\text { Hanya da pencatatan uang } \\
\text { masuk dan uang keluar, } \\
\text { tidak pernah ada identifikasi } \\
\text { dan pencatatan biaya }\end{array}$ \\
\hline
\end{tabular}




\begin{tabular}{|c|l|l|}
\hline 11 & Wawan Motor & $\begin{array}{l}\text { Hanya da pencatatan uang } \\
\text { masuk dan uang keluar, } \\
\text { tidak pernah ada identifikasi } \\
\text { dan pencatatan biaya }\end{array}$ \\
\hline 12 & $\begin{array}{l}\text { Tk.TongHilapnya } \\
\text { Buah Manis }\end{array}$ & $\begin{array}{l}\text { Sudah ada pencatatan } \\
\text { manual pada pembelian, } \\
\text { penjualan, uang masuk dan } \\
\text { uang keluar, namun tidka } \\
\text { ada catatan persediaan dna } \\
\text { belum mampu membuat } \\
\text { laporan keuangan }\end{array}$ \\
\hline
\end{tabular}

Setelah melakukan identifikasi awal, setiap kelompok membuat rencana kerja yang diseuaikan dengan materi yang sudah ditentukan. Tahap kedua setelah identifiaksi adalah membuat Sisntem Informasi akuntansi yang sesuai dengan masing masing UKM, membantu membuat SOP akuntansi serta formulir/dokumen dokumen yang harus di buat. Contohnya Ketika membuat Sistem Informasi Penerimaan Kas, termasuk membuatkan bukti penerimaan kas, buku kas, dan akun akun terkait penerimaan kas.

Pada tahap selanjjutnya, adalah membuat platform dasar system komputerisasi akuntansi berbasis excel berdasarkan system informasi akuntansi yang sudah di buat. Dikarenakan jenis perusahaan berbeda maka, system yang dibangun juga di sesuaikan dengan kondisi Mitra UKM.

Tahap ketiga adalah melakukan trial atau uji coba system yang sudah di buat. Data yang dipakai untuk uji coba adalah data actual mitra selama satu bulan terakhir. Uji coba dilakukan dalam dua tahap, tahap pertama dilakukan oleh kelompok pendamping dan tahap kedua adalah Mitra UKM.

Tahap keempat adalah uji coba penuh, yaitu memasukan semua data keuangan selama tahun 2018. Hal ini dilaukan oleh Mitra di bantu dengan kelompok pendamping. Contoh hasil dari uji coba penuh pada Tk Buah Amparan seperti berikut :

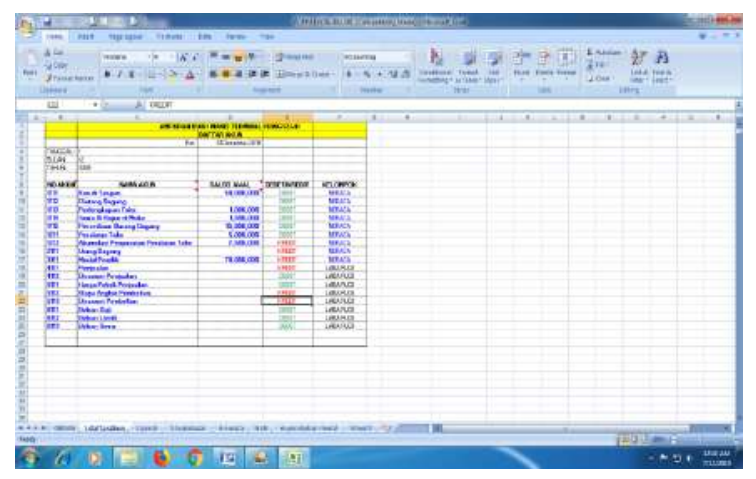

Buku Besar : Toko Buah Amparan Buah Manis

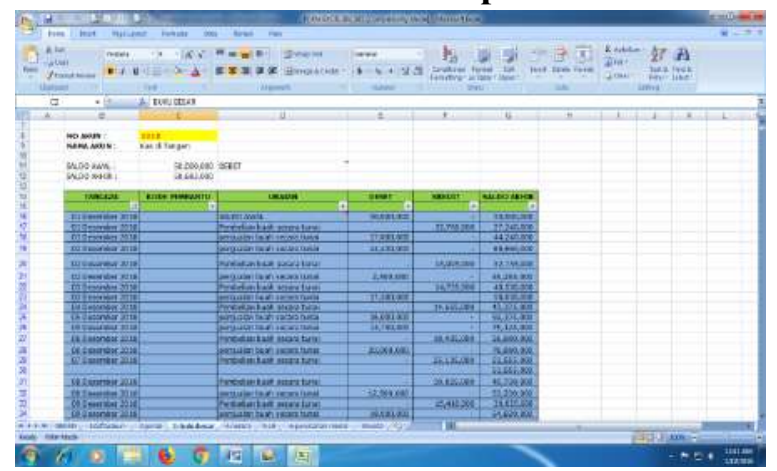

Tahap terahir adalah tahap pembahasan hasil dan evaluasi. Diadakan pembahasan Antara MItra, Kelompok Pendamping dan Dosen. Mitra UKM banyak sekali memberikan masukan yang positif bagi perbaikan program pendampingan yang akan datang.

\section{KESIMPULAN DAN SARAN}

Berdasarkan keseluruhan proses pelatihand an pendampinagn yang telah dilakukan di dapatkan kesimpulan sebagai berikut:

\section{Kesimpulan:}

1. Akuntansi sangat penting dalam pengellolaan keuanagn unit usaha. Pencatatan keuangan tidaklah sama dengan pembukuan. Tanpa Melakukan pembukuan dengan benar pengusaha tidak akan mampu mengevaluasi dan mengetahui kondis keuanga nusaha nya secara riil.

2. Pemakaian tekhnologi computer sangat membantu pengusaha dalam mengolah transaksi keuangan. Pembuatan laporan keuangan menjadi sederhana dan lebih cepat. 
3. UMKM yang membutuhkan pendampingan sangat banyak. Hal ini perlu mendapatkan perhatian dari pemerintah dan pergurruan tinggi sebagai mitra. Potensi UMKM yang sangat strategis dalam menyerap tenaga kerja dan distribusi pendapatm harus di tanggapi dengan program program [emerinta yang lebih mengena. Selama ini pelatihan yang dilakukan pemerintah apda umumnya hanya bersifat pemberian materi saja.

\section{Saran:}

1. Pemerintah sebaiknya melakukan pelatihan yang bersifat lebih praktik dengna pendekatan yang lebih personal dan sesuai dengan kebutuhan UMKM. Saat ini kebanyakan pelatihan dan pendampingan bersifat teori dan tidak mengajarkan pengetahuan praktis dalam pengelolaan Usaha.

2. Tingkat pengetahuan UMKM terhadap pengelolaan keuangan usaha sangat terbatas sehingga pendmapingan secara intensif perlu di lakukan. Oleh Karen aitu, kerjasama Antara pemerintah dan perguruan tinggi harus lebih sering dilakukan.

\section{DAFTAR PUSTAKA}

Abou-Shouk, M \& Eraqi, M. 2015. Perceived barriers to e-commerce adoption in SMEs in developing countries : the case of travel agents in Egypt. International Journal of Services andOperations Management, 21(3), 332-353.

Arief, Mohammad, et al. 2013. "The effect of entrepreneurial orientation on the firm performance through strategic flexibility: A study on the SMEs cluster in Malang." Journal of Management Research 5.3 : 44-62.

Barry, A., Rodriquez, E., and Sandee, H. 2014. 'Firm and Group Dynamics in the Small and Medium Enterprise Sektor in

\author{
Indonesia', Small Business Economics \\ Journal, v.8, pp. $141-61$
}

Bappenas. 2016. Penguatan UMKM untuk pertumbuhan ekonomi yang Berkualitas. Warta KUMKM V.5 No. 1- 2016

Kusnindar, Arum. 2017. "Profiling UMKM di Kabupaten Prinngsewu Sebagai Basis Menciptakan Program Pemberdayaan yang tepat Sasaran”. Journal Multi Science STIE Muhammadiyah pringsewi, Vol 1, 17 - 28

Malia., Siti. 2018. Pengaruh Pengetahuan Akuntansi pada Penyusunan Laporan Keuangan di pada Pengurus Koperasi Kabupaten Pringsewu. Skrpsi S1, STIE Muhammadiyah Pringsewu. Tidak Untuk Di Publikasikan. 